\title{
PENGARUH EFEK ENTRENCHMENT, ALIGMENT DAN DEWAN KOMISARIS INDEPENDEN TERHADAP VOLUNTARY DISCLOSURE PADA PERUSAHAAN OTOMOTIF YANG TERDAFTAR DI BURSA EFEK INDONESIA PERIODE 2014-2017
}

\author{
Sri Mulyati ${ }^{1}$, Rauzatul Jannah ${ }^{2}$ \\ ${ }^{1,2}$ Prodi Akuntansi Fakultas Ekonomi dan Bisnis Universitas Malikussaleh Lhokseumawe \\ ${ }^{1}$ Sri.byan@gmail.com, ${ }^{2}$ rauza22.jannah@gmail.com
}

\begin{abstract}
This study aims to know the Effect of Entrenchment Effects, Alignment and Independent Board of Commissioners toward Voluntary Disclosure of Automotive Companies Listed on the Indonesia Stock Exchange during 2014-2017. The data used in this study are secondary data as many as 12 samples with 48 observations. The sampling technique used is purposive sampling technique. The method used to analyze the relationship between the independent variables and the dependent variable is the multiple linear regression method and the classical assumption test. The results showed that the entrenchment and alignment partially has a negative and significant effect on Voluntary Disclosure of Automotive Companies listed on the Indonesia Stock Exchange, while independent commissioners have a positive and significant effect on Voluntary Disclosure of Automotive Companies listed on the Indonesia Stock Exchange. Simultaneously, the entrenchment, alignment and independent board of commissioners have a positive and significant effect on Voluntary Disclosure of Automotive Companies listed on the Indonesia Stock Exchange.
\end{abstract}

Keywords: Voluntary Disclosure, Entrenchment, Alignment and Independent Board of Commissioners

\section{PENDAHULUAN}

Perkembangan teknologi dan globalisasi yang begitu besar dewasa ini menimbulkan persaingan kompetitif dalam dunia usaha.Perkembangan lingkungan juga ikut serta memberikan pengaruh dalam dunia usaha bisnis. Untuk menghadapi persaingan yang ketat, perusahaan dihadapkan pada kondisi untuk dapat lebih transparan dalam mengungkapkan informasi perusahaannya, sehingga akan lebih membantu para pengambil keputusan dalam mengantisipasi kondisi perekonomian yang semakin berubah. Informasi perusahaan yang diungkapkan tersebut tertuang dalam suatu laporan tahunan perusahaan.

Agar informasi dapat diinterpretasikan secara tepat, mudah dipahami, dan tidak menyesatkan pihakpihak yang berkepentingan, maka harus disusun sesuai standar yang berlaku dan juga perusahaan diharapkan untuk dapat lebih transparan dalam mengungkapkan informasi keuangan perusahaannya.Namun sejauh informasi yang dapat diperoleh sangat bergantung pada tingkat pengungkapan (disclosure level) dari laporan perusahaan yang bersangkutan (Nahda dan Harjito, 2011).Pengungkapan berperan penting dalam pasar modal yang efisien dimana pengungkapan tersebut berupa laporan tahunan. Laporan tahunan mengkomunikasikan kondisi keuangan dan informasi lain kepada berbagai stakeholder, yang bertujuan untuk memberikan informasi yang relevan dan tepat waktu, agar bermanfaat didalam pengambilan keputusan investasi, monitoring, penghargaan kinerja dan pembuatan kontrak-kontrak.

Voluntary disclosure level di pengaruhi oleh efek Entrenchment,Alignment dan Dewan Komisaris Independen.Entrenchment adalah tindakan pemegang saham pengendali yang dilindungi oleh hak kontrolnya untuk melakukan ekspropriasi (Fan dan Wong, 2002). Ekspropriasi adalah suatu proses penggunaan hak kontrol atau kendali seseorang untuk memaksimalkan kesejahteraan sendiri dengan distribusi kekayaan dari pihak lain (Claessens et al., 1999) dalam Sanjaya (2010). Menurut Sanjaya (2010) Peningkatan ekspropriasi oleh pemegang saham pengendali mengimplikasikan efek entrenchment Karena, pemegang saham pengendali memiliki kendali yang kuat untuk menggunakan perusahaan dalam usaha memenuhi kepentingannya dibanding kepentingan seluruh pemegang saham.

Menurut Sanjaya (2010) efek Alignment adalah tindakan pemegang saham pengendali yang selaras dengan kepentingan pemegang saham nonpengendali. Menurut Yeh (2005), lebih besar konsentrasi hak aliran kas di tangan pemegang saham pengendali lebih besar insentifnya memiliki perusahaan yang dijalankan secara benar. Kenaikan hak aliran kas memotivasi pemegang saham pengendali untuk tidak melakukan ekspropriasi.Hal ini bisa jadi memotivasi pemegang saham pengendali untuk tidak melakukan manajemen laba. Menurut Sanjaya (2010) Pemegang saham pengendali juga memiliki insentif yang kuat untuk 
mengawasi manajer dan memaksimalkan laba ketika ia mempunyai hak aliran kas yang substansial. Hal ini menunjukkan komitmen pemegang saham pengendali untuk tidak melakukan ekspropriasi.Ekspropriasi sangat mungkin dilakukan karena pemegang saham pengendali dapat memanfaatkan keterbatasan-keterbatasan hukum dalam suatu negara yang menganut hukum civil seperti Indonesia.

Dewan Komisaris merupakan organ perusahaan yang memiliki tugas dan tanggungjawab secara kolektif untuk melakukan pengawasan kepada Dewan Direksi serta memastikan bahwa perusahaan telah menerapkan sistem tata kelola perusahaan yang baik (good corporate governance/GCG) (KNKG, 2006).Fungsi pengawasan yang dilakukan oleh Dewan Komisaris juga ditingkatkan melalui penerbitan Peraturan Otoritas Jasa Keuangan No. 33/POJK.04/2014 tentang Direksi dan Dewan Komisaris Emiten atau Perusahaan Publik. Dalam peraturan tersebut, komposisi dewan komisaris pada perusahaan publik harus memiliki anggota Dewan Komisaris Independen3 yang berjumlah minimal sebesar $30 \%$ dari jumlah dewan komisaris perusahaan. Kehadiran dewan komisaris independen diharapkan dapat meningkatkan efektifitas fungsi pengawasan oleh Dewan Komisaris terhadap Dewan Direksi.Peningkatan kualitas pengawasan ini diharapkan dapat meningkatkan tingkat kepercayaan dari kreditur, sehingga dapat memberikan biaya utang yang lebih rendah.

Dalam rangka mendukung efektivitas pelaksanaan tugas dan tanggung jawabnya, Dewan Komisaris dapat membentuk beberapa komite untuk membantu menjalankan tugas pengawasannya. KomiteKomite yang dapat menunjang fungsi Dewan Komisaris dapat berupa Komit Audit, Komite Nominasi dan Remunerasi, Komite Kebijakan Risiko, Komite Kebijakan Corporate Governance, dan lain-lain. Bagi perusahaan yang mendaftarkan sahamnya di bursa efek, perusahaan negara atau daerah, perusahaaan yang menghimpun dan mengelola dana masyarakan, perusahaan yang produk atau jasanya digunakan oleh masyarakat luas, serta perusahaan yang mempunyai dampak luas terhadap kelestarian lingkungan, sekurangkurangnya harus membentuk Komite Audit, sedangkan komite lainnya dibentuk sesuai dengan kebutuhan perusahaan

Namun berdasarkan pengamatan pada perusahaan Otomotif, beberapa perusahaan seperti Astra Autopart dan perusahaan Gajah Tungga Tbk tidak menyampaikan keseluruhan informasi sukarela seperti prospek bisnis dan peningkatan produk dan jasa dalam laporan tahunan perusahaan. Rendahnya penyampaian informasi sukarela karena besarnya kepemilikan yang dikuasai oleh pemilik perusahaan.

Berdasarkan tabel 1.2 dalam dilihat bahwa pada perusahan Astra international Tbk pada tahun 2015-2017 nilai entrenchment, tidak mengalami fluktuasi yaitu sebesar 3,91 dengan voluntary disclosure pada tahun 2015 sebesar 65,00 tetapi pada tahun 2016 mengalami penurunan menjadi 63,00. Pada tahun 2014- 2017 alignment tetap memiliki nilai yang sama dari tahun sebelumnya yaitu sebesar 26,68 akan tetapi voluntary disclosure mengalami penurunan pada tahun 2016 yaitu sebesar 63,00. Pada tahun 2014- 2017 dewan komisaris independen berjumlah 3 orang, akan tetapi voluntary disclosure mengalami penurunan pada tahun 2016 yaitu sebesar 63,00.

Perusahaan Astra Autopart Tbk pada tahun 2015 entrechment mengalami penurunan dari tahun sebelumnya yaitu 0,00 tetapi voluntary disclosure juga ikutmengalami penurunan juga yaitu sebesar 65,00, pada tahun 2015-2017 alignment memiliki nilai yang sama yaitu sebesar 26,68 tetapi voluntary disclosure mengalami penurunan yaitu sebesar 65,00. Pada tahun 2014 - 2017 dewan kumisaris independen berjumlah 4 orang akan tetapi voluntary disclosure mengalami penurunan pada tahun 2016 yaitu sebesar 63,00.

Perusahaan Garuda Multi Investama Tbk pada tahun 2016 mengalami penurunan dari tahun sebelumnya yaitu sebesar 7,79 dengan voluntary disclosure juga mengalami penurunan pada tahun 2016 yaitu sebesar 63,00. Pada tahun 2016 komisaris independen berjumlah 2 orang menalami peningkatan dari tahun sebelumnya maka voluntary disclosure malah mengalami penurunan yaitu sebesar 61,00.

PT. Gajah Tunggal Tbk pada tahun 2014-2015 memiliki nilai entrenchment yang sama yaitu 3,92 dengan voluntary disclosure pada tahun 2016 mengalami peningkatan yaitu sebesar 63,00.pada tahun 2014-2015 memiliki nilai aligment yang sama yaitu 27,48 dengan voluntary disclosure pada tahun 2016 mengalami peningkatan yaitu sebesar 63,00.

PT. Indomobil Sukses Internasional Tbk pada tahun 2015 nilai entrenchment mengalami penurunan dari tahu sebelumnya yaitu sebesar 5,07 akan tetapi voluntary disclosure pada tahun 2015 tetap memiliki nilai yang sama dengan nilai tahun sebelumnya yaitu sebesar 69,00 begitu juga sebaliknya. Pada tahun 2014-2017 nilai aligment tetap sama yaitu 26,93 tetapi voluntary disclosure pada tahun 2016 malah mengalami penurunan yaitu sebesar 65,00. Pada tahun 2014-2017 dewan komisaris independen berjumlah 3 orang tetapi voluntary disclosure pada tahun 2016 malah mengalami penurunan yaitu sebesar 65,00. PT. Indospring Tbk dewan komisaris pada tahun 2016 berjumlah 1 orang lebih sedikit dari tahun sebelumnya, tetapi malah voluntary disclosure tetap memiliki nilai yang sama pada tahun 2016 sebesar 69,00.

PT. Multi Prima Sejahtera Tbknilai entrechnment menurun pada tahun 2016 sebesar 20,09 tetapi voluntary disclosure mengalami peningkatan yaitu sebesar 69,00. dewan komisaris pada tahun 2016 berjumlah 1 orang lebih sedikit dari tahun sebelumnya yang berjumlah 2 
orang, tetapi malah voluntary disclosure mengalami peningkatan sebesar 69,00.

PT. Multistrada Arah Sarana Tbk nilai entrechnment menurun pada tahun 2015 sebesar 11,63 tetapi voluntary disclosure tetap memiliki nilai yang sama dari tahu 2014-2017 yaitu sebesar 65,00. nilaialigment meningkat pada tahun 2017 sebesar 26,20 tetapi voluntary disclosure tetap memiliki nilai yang sama dari tahun 2014-2017 yaitu sebesar 65,00. PT. Nipress Tbk jumlah dewan komisaris pada tahun 2016 berjumlah 5 orang lebih banyak dari tahun sebelumnya tetapi malah voluntary disclosure malah memiliki nilai 67,00 .

Secara teori semakin tinggi entrechnment maka akan menyebabkan voluntary disclosure akan menurun tetapi pada PT. Garuda Multi Investama pada saat entrechnmentmengalami penurunan justru voluntary disclosure ikut menurun. Semakin meningkat aligment maka voluntary disclosureakan mengalami peningkatan juga, tetapi pada PT.Goodyear Indonesia Tbk ketika aligment menurun voluntary disclosure justru meningkat. Semakin meningkat dewan komisaris independen maka akan semakin meningkat juga voluntary disclosure. Tetapi yang terjadi pada PT. Nipress Tbk ketika dewan komisaris independen mengalami peningkatan voluntary disclosure justru mengalami penurunan.

Berdasarkan latar belakang tersebut di atas maka peneliti tertarik untuk melakukan penelitian dengan judul "Pengaruh Efek Entrenchment, Aligment Dan Dewan Komisaris Independen Terhadap Voluntary Disclosure Pada Perusahaan Otomotif Yang Terdaftar Di Bursa Efek Indonesia Periode 20142017'. Berdasarkan latar belakang di atas maka rumusan masalah dalam penelitian ini adalah sebagai berikut :Apakah Efek Entrenchment berpengaruh terhadap Voluntary Disclosure Level Pada Perusahaan Otomotif yang terdaftar di Bursa Efek Indonesia?, Apakah Alignment berpengaruh berpengaruh terhadap Voluntary Disclosure Level Pada Perusahaan Otomotif yang terdaftar di Bursa Efek Indonesia?, Apakah Dewan Komisaris Independen berpengaruh terhadap berpengaruh terhadap Voluntary Disclosure Level Pada Perusahaan Otomotif yang terdaftar di Bursa Efek Indonesia?, Apakah Efek Entrenchment, Alignment dan Dewan Komisaris Independen berpengaruh terhadap Voluntary Disclosure Level Pada Perusahaan Otomotif yang terdaftar di Bursa Efek Indonesia?Berdasarkan latar belakang dan rumusan masalah tersebut di atas maka tujuan penelitian ini adah sebagai berikut :Untuk mengetahui Apakah Efek Entrenchment berpengaruh berpengaruh terhadap Voluntary Disclosure Level Pada Perusahaan Otomotif yang terdaftar di Bursa Efek Indonesia.Untuk mengetahui Apakah Alignment berpengaruh berpengaruh terhadap Voluntary Disclosure Level Pada Perusahaan Otomotif yang terdaftar di Bursa
Efek Indonesia.Untuk mengetahui Apakah Dewan Komisaris Independen berpengaruh terhadap berpengaruh terhadap Voluntary Disclosure Level Pada Perusahaan Otomotif yang terdaftar di Bursa Efek Indonesia?Untuk mengetahui Apakah Efek Entrenchment, Alignment dan Dewan Komisaris Independen berpengaruh terhadap Voluntary Disclosure Level Pada Perusahaan Otomotif yang terdaftar di Bursa Efek Indonesia.

\section{TINJAUAN PUSTAKA \\ Landasan Teori \\ Theory Agency}

Menurut Anthony dan Govindarajan (1995) dalam Widyaningdyah (2001) menyatakan bahwa konsep agency theory adalah hubungan atau kontrak yang terjadi antara principal dan agent.Principalmempekerjakanagent untuk kepentingan principal, termasuk pendelegasian otoritas pengambilan keputusan dari principal kepada agent. Teori agensi adalah pengembangan dari suatu teori yang mempelajari suatu desain kontrak dimana para agent bekerja atau bertugas atas namaprincipal ketika keinginan atau tujuan mereka bertolak belakang maka akan terjadi suatu konflik (Scott, 2006).

Pada perusahaan yang modalnya terdiri atas saham, pemegang saham bertindak sebagai principal, dan CEO sebagai agent mereka untuk bertindak sesuai dengan kepentingan principal.Agency theory memiliki asumsi bahwa masing-masing individu semata-mata termotivasi oleh kepentingan dirinya sendiri sehingga menimbulkan konflik kepentingan antara principal dan agent.Pihak principal termotivasi mengadakan kontrak untuk mensejahterakan dirinya dengan profitabilitas perusahaannya yang selalu meningkat.

Hubungan agent dan principal harus memiliki kepercayaan yang kuat, dimana agent melaporkan segala informasi perkembangan perusahaan yang dimiliki oleh principal melalui segala bentuk informasi akuntansi karena hanya manajemen yang mengetahui pasti keadaan perusahaan.Pemisahan antara pengelola dan pemilik perusahaan sangat rentan terhadap masalah yang disebut sebagai masalah keagenan (agency problem).

Dalam hal ini terdapat dua kepentingan yang berbeda antara principal dan agent. Masing-masing pihak akan berusaha untuk meningkatkan keuntungannya. Perbedaan kepentingan antara agent dan principal inilah yang akan memicu timbulnya konflik kepentingan. Sehingga penelitian ini merujuk pada teori keagenan sebagai acuan untuk menjelaskan konflik yang terjadi antara manajemen dan pemegang saham berkaitan dengan kebijakan dividen.

Menurut Ujiyanto dan Bambang (2007) teori agensi menggunakan tiga asumsi sifat manusia, yaitu:

1. Manusia pada umumnya mementingkan diri sendiri (self interest). 
2. Manusia memiliki daya pikir terbatas menegenai persepsi masa mendatang (bounded rationality).

3. Manusia selalu menghindari risiko (risk adverse). Agent termotivasi untuk memaksimalkan pemenuhan kebutuhan ekonomi dan psikologisnya, antara lain dalam hal memperoleh investasi, pinjaman, maupun kontrak kompensasi. Konflik kepentingan semakin meningkat terutama karena principal tidak dapat memonitor aktivitas CEO sehari-hari untuk memastikan bahwa CEO bekerja sesuai dengan keinginan pemegang saham.Principaltidak memiliki informasi yang cukup tentang kinerja agent. Agent mempunyai lebih banyak informasi mengenai perusahaan secara keseluruhan.Hal inilah yang mengakibatkan adanya ketidakseimbangan informasi yang dimiliki oleh principal dan agent (Nasution dan Doddy, 2007).

Ketidakseimbangan informasi inilah yang disebut dengan asimetri informasi.Adanya asumsi bahwa individu-individu bertindak untuk memaksimalkan dirinya sendiri, mengakibatkan agent memanfaatkan adanya asimetri informasi yang dimilikinya untuk menyembunyikan beberapa informasi yang tidak diketahui principal.Hal ini dapat memacu agent untuk memikirkan bagaimana angka akuntansi tersebut dapat digunakan sebagai sarana untuk memaksimalkan kepentingannya.Tindakan agent tersebut bisa disebut praktik manajemen laba (earning management).

Smith dan Warner (1979) dalam Godfrey et al. (2010) juga menjelaskan bahwa terdapat beberapa tindakan pemegang saham pengendali yang dapat memicu terjadinya konflik keagenan dengan kreditur, seperti pembayaran dividen yang terlalu besar kepada pemegang saham, penggunaan dana pinjaman untuk berinvestasi pada aset yang berisiko tinggi atau pada proyek yang memiliki net present value yang negatif, dan penerbitan kontrak utang baru dengang prioritas yang lebih tinggi dibandingkan kontrak utang sebelumnya.

Hal-hal tersebut membuat pihak kreditur harus meningkatkan suku bunga pinjaman yang diberikan kepada perusahaan. Dalam hal ini, Suku bunga pinjaman tidak hanya menjadi imbal balik atas investasi dari kreditur, namun juga untuk mengkompensasi risiko kredit yang dihadapinya Lin, Chen dan Yen (2014), dan Boubakri dan Ghouma (2010) membuktikan bahwa terdapat hubungan positif antara perbedaan hak kontrol dan hak arus kas dari pemegang saham pengendali akhir terhadap biaya utang perusahaan. Dalam penelitian tersebut, Lin, Chen, dan Yen (2014) juga menjelaskan bahwa fungsi pengawasan dalam sistem tata kelola perusahaan merupakan salah satu bahan pertimbangan yang penting bagi pihak kreditur dalam menetapkan biaya utang.

Dalam mekanisme kepemilikan piramida, pemegang saham pengendali akhir dapat meningkatkan hak kontrol dibandingkan hak arus kasnya (La Porta et al., 1999 ; Fan dan Wong, 2002). Fan dan Wong (2002) menjelaskan bahwa hak kontrol yang lebih tinggi dibandingkan hak arus kasnya akan cenderung menimbulkan efek entrenchment yang negatif. Dalam kondisi ini, pemegang saham pengendali akhir dapat mengendalikan penyajian informasi akuntansi dan kebijakan penyajian laporan keuangan yang digunakan didalam perusahaan (Fan dan Wong, 2002).

Hal ini menyebabkan adanya permasalahan asimetri informasi antara pemegang saham pengendali dengan pemangku kepentingan lainnya, seperti kreditur (La Porta et al., 2000). Asimetri informasi ini menimbulkan konflik keagenan lain yang biasa dikenal sebagai konflik keagenan shareholder-debtholders. Asimetri informasi yang terjadi didalam perusahaan membuat pihak kreditur tidak dapat mengolah informasi secara akurat mengenai kegiatan operasional perusahaan (Chan dan Hsu, 2013). Hal ini juga menyulitkan pihak kreditur untuk menentukan estimasi pembayaran atas pinjaman yang diberikan (Lin, Chen, dan Yen, 2014).

\section{Efek Entrenchment}

Entrenchment adalah tindakan pemegang saham pengendali yang terlindung oleh hak kendali (hak kontrol) mereka, sehingga terlibat dalam penyalahgunaan Kekuasaan.Pemegang saham pengendali dengan hak kontrol yang kuat menggunakan perusahaan untuk kepentingan pribadi dibanding kepentingan pemegang saham nonpengendali.Hal ini mengimplikasikan efek entrenchment pemegang saham pengendali.Entrenchment adalah tindakan pemegang saham pengendali yang dilindungi oleh hak kontrolnya untuk melakukan abuse of power seperti ekspropriasi (Fan dan Wong, 2002). Fan dan Wong (2005) dan Yeh (2005) juga menegaskan hal sama. pemegang saham pengendali memiliki kendali yang kuat untuk menggunakan perusahaan dalam usaha memenuhi kepentingannya dibanding kepentingan seluruh pemegang saham (Bozec dan Laurin, 2008).

Efek entrenchment mencakup ekspropriasi laba perusahaan yang ditransfer kepada perusahaan lain yang masih dikendalikan oleh pemegang saham pengendali. Pemegang saham pengendali dapat juga melakukan ekspropriasi tentang pencarian tujuan yang tidak memaksimalkan laba perusahaan.Dekker (2014) menjelaskan bahwa karakteristik pada perusahaan keluarga yaitu adanya hubungan keluarga antara Dewan Direksi ataupun Dewan Komisaris dengan pihak pemegang saham pengendali perusahaan.hal ini memungkinkan pemegang saham pengendali akhir untuk memperoleh informasi yang lebih akurat dibandingkan pemegang saham lainnya, sehingga terciptanya asimetri informasi di dalam perusahaan

Mekanisme kepemilikan piramida cenderung terdapat pada perusahaan-perusahaan di negara yang 
memiliki tingkat perlindungan pemegang saham yang rendah. Adapun efek entrenchment dapat dihitung dengan menggunakan proksi sebagai berikut:

Efek Entrenchment $=$ Hak Kontrol - Hak Arus Kas Keterangan :

Hak Kontrol : Merupakan hak suara untuk ikut serta dalam menentukan kebijakan perusahaan, hak kontrol terdiri atas dua yaitu :

- Hak Kontrol Langsung

Yaitu persentase saham yang dimiliki oleh pemegang saham pengendali atas nama dirinya pada sebuah perusahaan.

- Hak Kontrol Tidak Langsung

Yaitu penjumlahan atas hasil kontrol minimum dalam setiap rantai kepemilikan.

Hak Aliran : Merupakan klaim keuangan pemegang Kas saham terhadap perusahaan hak aliran kas terdiri atas dua yaitu :

- Hak Aliran Kas Langsung

Yaitu persentase saham yang dimiliki oleh pemegang saham pengendali pada perusahaan publik atas nama dirinya sendiri.

- Hak Aliran Kas Tidak Langsung

Hasil perkalian persentase saham dalam setiap rantai kpemilikan.

\section{Alignment}

Pemegang saham pengendali juga dapat menimbulkan efek positif, yaitu alignment effect.Alignment adalah tindakan pemegang saham pengendali yang selaras dengan kepentingan pemegang saham non pengendali.Menurut Yeh (2005) dalam Sanjaya (2010), lebih besar konsentrasi hak aliran kas di tangan pemegang saham pengendali lebih besar insentifnya memiliki perusahaan yang dijalankan secara benar.Kenaikan hak aliran kas memotivasi pemegang saham pengendali untuk tidak melakukan ekspropriasi.Alignment effect antara pemegang saham pengendali dan pemegang saham minoritas ini berdampak pada meningkatnya pengungkapan sukarela perusahaan, karena pemegang saham pengendali akan lebih berkomitmen menjalankan perusahaan sebaik mungkin untuk menghindari kerugian yang tidak diinginkan serta membangun reputasi yang baik bagi perusahaan (Fan dan Wong, 2002 dalam Sanjaya, 2010).

Pemegang saham pengendali memiliki hak aliran kas yang cukup untuk mencegah keinginannya untuk mengekspropriasi pemegang saham nonpengendali dan perusahaan.Lebih besar konsentrasi hak aliran kas, lebih besar insentif pemegang saham pengendali menjalankan perusahaan secara benar.Hal ini mengimplikasikan efek alignment.Alignment adalah tindakan pemegang saham pengendali yang selaras dengan kepentingan pemegang saham nonpengendali (Sanjaya, 2010).

Kepemilikan aliran kas oleh pemegang saham pengendali mengurangi keinginannya untuk mengekspropriasi dan meningkatkan keinginannya untuk membayar dividen tunai Jensen dan Meckling, (1976) dalam Sanjaya (2010).Hak aliran kas yang lebih besar merupakan komitmen pemegang saham pengendali untuk membatasi ekspropriasi (La Porta et al., 1999). Hal yang sama juga dikemukan oleh Gomes (2000). Karena, ekspropriasi juga merugikan pemegang saham pengendali (Claessens dan Fan, 2002).

Pengukuran efek alignment mengacu kepada penelitian Lin et al. (2011) dan Bozec et al. (2012) dalam Diyanty dan Yodhianto (2012).Efek alignment dapat diukur dari besarnya nilai hak arus kas pemegang saham pengendali akhir. Adapun efek alignment dapat dihitung dengan menggunakan proksi sebagai berikut

$\mathrm{CFR}=$ Total Hak arus kas pemegang saham pengendali akhir

\section{Dewan Komisaris Independen}

Dewan komisaris merupakan organ perseroan kedua dalam struktur corporate governance yang memiliki fungsi kontrol dalam perusahaan.Fungsi kontrol yang dilakukan oleh dewan komisaris bertujuan untuk melakukan pengawasan secara umum dan atau khusus sesuai dengan anggaran dasar serta memberi pertimbangan-pertimbangan kepada direksi.

Menurut Hastuti (2011:64), komisaris independen adalah anggota dewan komisaris yang tidak berafiliasi dengan manajemen, anggota dewan komisaris lainnya dan pemegang saham pengendali, serta bebas hubungan bisnis atau hubungan lainnya yang dapat mempengaruhi kemampuannya untuk bertindak independen atau bertindak semata-mata demi kepentingan perusahaan.

Berdasarkan Keputusan Direktur Bursa Efek Jakarta (KEP-339/BEJ/07-2001) Bahwa setiap perusahan publik wajib memiliki komisaris independen untuk mencipatakan tata kelola perusahaan yang baik. Komisaris independen berjumlah sebanding dengan jumlah saham yang di miliki oleh pemengang saham pengendali dengan ketentuan jumlah komisaris independen sekurang-kurangnya $30 \%$ dari jumlah anggota komisaris.

Bapepam IX.I.5 juga mendefinisikan bahwa yang dimaksud dengan Komisaris Independen adalah komisaris yang berasal dari luar emiten atau perusahaan publik, tidak mempunyai saham baik langsung maupun tidak langsung pada emiten atau perusahaan publik, tidak mempunyai hubungan afiliasi dengan emiten atau perusahaan publik, komisaris, atau pemegang saham utama emiten atau perusahaan publik, dan tidak memiliki hubungan usaha baik langsung maupun tidak langsung 
yang berkaitan dengan kegiatan usaha emiten atau perusahaan publik. Adapun dewan komisaris independendapat dihitung dengan menggunakan proksi sebagai berikut: Jumlah dewan komisaris.

\section{Tugas - Tugas Dewan Komisaris}

Komisaris independen berjumlah sebanding dengan jumlah saham yang di miliki oleh pemengang saham pengendali dengan ketentuan jumlah komisaris independen sekurang-kurangnya $30 \%$ dari jumlah anggota komisaris.Menurut KNKG (2006) menjelaskan bahwa dewan komisaris Independen mempunyai tugastugas sebagai berikut :

1. Menilai dan mengarahkan strategi perusahaan, garisgaris besar rencana kerja, kebijakan pengendalian risiko, anggaran tahunan dan rencana usaha; menetapkan sasaran kerja; mengawasi pelaksanaan dan kinerja perusahaan; serta memonitor penggunaan modal perusahaan, investasi dan penjualan aset

2. Menilai sistem penetapan penggajian pejabat pada posisi kunci dan penggajian anggota Dewan Direksi, serta menjamin suatu proses pencalonan anggota Dewan Direksi yang transparan dan adil.

3. Memonitor dan mengatasi masalah benturan kepentingan pada tingkat manajemen, anggota Dewan Direksi dan anggota Dewan Komisaris, termasuk penyalahgunaan aset perusahaan dan manipulasi transaksi perusahaan

4. Memonitor pelaksanaan Governance, dan mengadakan perubahan jika perlu

5. Memantau proses keterbukaan dan efektifitas komunikasi dalam perusahaan (OECD Principles of Corporate Governance).

\section{Pertanggungjawaban Dewan Komisaris}

Dewan komisaris harus dapat menjalankan fungsinya di tengah lingkungan bisnis yang kompleks dengan baik, dewan komisaris perlu membentuk komitekomite yang membantunya menjalankan tugas, salah satunya adalah komite audit. Menurut Puspitasari (2014) Pertanggungjawaban dewan komisaris terdiri dari :

1. Dewan komisaris dalam fungsinya sebagai pengawas, menyampaikan laporan pertanggungjawaban pengawasan atas pengelolaan perusahaan oleh direksi. Laporan pengawasan dewan komisaris merupakan bagian dari laporan tahunan yang disampaikan kepada RUPS untuk memperoleh persetujuan.

2. Dengan diberikannya persetujuan atas laporan tahunan dan pengesahan atas laporan keuangan, berarti RUPS telah memberikan pembebasan dan pelunasan tanggung jawab kepada masing-masing anggota dewan komisaris sejauh hal-hal tersebut tercermin dari laporan tahunan, dengan tidak mengurangi tanggung jawab masing-masing anggota dewan komisaris dalam hal terjadi tindak pidana atau kesalahan dan atau kelalaian yang menimbulkan kerugian bagi pihak ketiga yang tidak dapat dipenuhi dengan aset perusahaan.

3. Pertanggungjawaban dewan komisaris kepada RUPS merupakan perwujudan akuntabilitas pengawasan atas pengelolaan perusahaan dalam rangka pelaksanaan asas GCG.

\section{Fungsi Pengawasan Dewan Komisaris}

Menurut Puspitasari (2014) fungsi pengawasan dewan komisaris terdiri dari :

1. Dewan Komisaris tidak boleh turut serta dalam mengambil keputusan operasional. Dalam hal dewan komisaris mengambil keputusan mengenai hal-hal yang ditetapkan dalam anggaran dasar atau peraturan perundangundangan, pengambilan keputusan tersebut dilakukan dalam fungsinya sebagai pengawas, sehingga keputusan kegiatan operasional tetap menjadi tanggung jawab direksi. Kewenangan yang ada pada dewan komisaris tetap dilakukan dalam fungsinya sebagai pengawas dan penasihat.

2. Dalam hal diperlukan untuk kepentingan perusahaan, dewan komisaris dapat mengenakan sanksi kepada anggota direksi dalam bentuk pemberhentian sementara, dengan ketentuan harus segera ditindak lanjuti dengan penyelenggaraan RUPS.

3. Dalam hal terjadi kekosongan dalam direksi atau dalam keadaan tertentu sebagaimana ditentukan oleh peraturan perundang-undangan dan anggaran dasar, untuk sementara dewan komisaris dapat melaksanakan fungsi direksi.

4. Dalam rangka melaksanakan fungsinya, anggota dewan komisaris baik secara bersama-sama dan atau sendiri-sendiri berhak mempunyai akses dan memperoleh informasi tentang perusahaan secara tepat waktu dan lengkap..

\section{Voluntary Disclosure}

Pengungkapan sukarela adalah pengungkapan informasi yang dilakukan secara sukarela oleh perusahaan tanpa diharuskan oleh peraturan BAPEPAM.Pengungkapan sukarela adalah pengungkapan melebihi yang diwajibkan.Menurut Evans (2003) Pengungkapan sukarela merupakan pilihan bebas manajemen perusahaan untuk memberikan informasi akuntansi dan informasi lainnya yang dipandang relavan untuk pengambilan keputusan oleh para pemakai laporan tahunanya.

Salah satu cara meningkatkan kredibilitas perusahaan adalah melalui pengungkapan sukarela secara lebih luas untuk membantu investor dalam memahami strategi bisnis manajemen. Pengungkapan Sukarela merupakan pengungkapan butir-butir yang dilakukan secara sukarela oleh perusahaan tanpa 
(telaahan keuangan yang menjelaskan karakteristik utama yang mempengaruhi kinerja perusahaan, posisi keuangan perusahaan, kondisi ketidakpastian, laporan mengenai lingkungan hidup, laporan nilai tambah) adalah merupakan pengungkapan yang dianjurkan (tidak diharuskan) dan diperlukan dalam rangka memberikan penyajian yang wajar dan relevan dengan kebutuhan pemakai.

Peraturan mengenai dokumen perusahaan yang harus diserahkan kepada Bapepam diatur dalam Keputusan Ketua Bapepam No. Kep40/PM/1997.Peraturan mengenai dokumen-dokumen yang terbuka untuk umum diatur dalam Keputusan Ketua Bapepam No. SE-24/PM/1987 menyatakan bahwa penyusunan laporan keuangan utama harus sesuai dengan Standar Akuntansi Indonesia yang dikeluarkan oleh Ikatan Akuntan Indonesia (IAI).

Berdasarkan penjelasan di atas dapat di simpulkan bahwa Pengungkapan Sukarela (voluntary disclosure) merupakan pengungkapan yang tidak diwajibkan peraturan, dimana perusahaan bebas memilih jenis informasi yang akan diungkapkan yang sekiranya dapat mendukung dalam pengambilan keputusan. Adapun voluntary disclosuredapat dihitung dengan menggunakan proksi sebagai berikut

$$
V D I=\frac{\text { TotalDisclosureScore }}{\text { TotalDisclisureItem }}
$$

\section{Indikator Pengungkapan Sukarela}

Menurut keputusan ketua badan pengawas pasar modal dan lembaga keuangan nomor: kep347/bl/2012 Tentang penyajian dan pengungkapan laporan keuangan emiten atau perusahaan publik indikator pengungkapan sukarela yaitu sebagai berikut :
A. Kinerja
B. Manajemen
C. Prospek
D. Pasar
E. Lain_lain

\section{Penelitian Sebelumnya}

Dwi Putri Oktaviani (2016)melakukan penelitian dengan judul Determinan Voluntary Disclosure Level: Studi Empiris Pada Perusahaan Manufaktur Yang Terdaftar Di Bursa Efek Indonesia. Hasil penelitian menunjukkan bahwa entrenchment effect dan alignment effect berpengaruh negatif terhadap voluntary disclosure level perusahaan, serta menunjukan dewan komisaris independen berpengaruh positif terhadap voluntary disclosure level perusahaan. Sedangkan free cash flow tidak berpengaruh terhadap voluntary disclosure level perusahaan.

Sanjaya (2010) melakukan penelitian dengan judul efek entrenchment dan alignment pada manajemen laba. hasil penelitian menunjukkan efek alignment berpengaruh negatif terhadap manajemen laba. Hak kendali mengendalikan pemegang saham pengendali mengelola penghasilan Ini berimplikasi pada efek entrenchment.Hak arus kas berpengaruh negatif terhadap manajemen laba Ini berimplikasi pada efek kesejajaran.

Fitriana (2014) melakukan penelitian dengn judul Faktor-Faktor Yang Mempengaruhi Luas Pengungkapan Sukarela Dalam Annual Report.Hasil penelitian menunjukkan bahwa profitabilitas, ukuran KAP, dan proporsi dewan komisaris independen berpengaruh positif terhadap luas pengungkapan sukarela, sedangkan leverage berpengaruh negatif terhadap luas pengungkapan sukarela.Sementara itu, ukuran perusahaan dan umur perusahaan tidak berpengaruh terhadap luas pengungkapan sukarela.

\section{Kerangka Konseptual}

Berdasarkan uraian di atas maka dapat di gambarkan dalam kerangkan sebagai berikut :

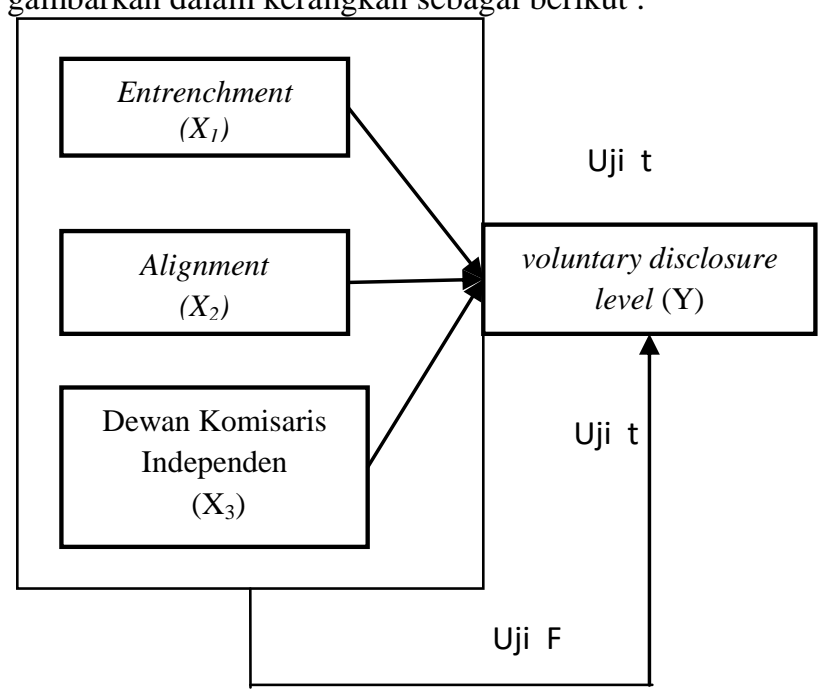

Gambar 1 Kerangka Konseptual

\section{Hipotesis}

Menurut Erlina dan Mulyani (2007) hipotesis adalah proporsi yang dirumuskan dengan maksud untuk diuji secara empiris. Berdasarkan perumusan masalah dan kerangka konseptual,hipotesis dalam penelitian ini adalah : 
$\mathrm{H}_{1}=$ Entrenchmentberpengaruh terhadap voluntary disclosure level pada perusahaan Otomotif di Bursa Efek Indonesia.

Alignment berpengaruh voluntary disclosure level

$\mathrm{H}_{2}=$ pada perusahaan Otomotif di Bursa Efek Indonesia. Dewan Komisaris Independen berpengaruh terhadap voluntary disclosure level pada perusahaan Otomotif di Bursa Efek Indonesia.

$\mathrm{H}_{3}=$ Entrenchment, Alignment dan Dewan Komisaris Independen berpengaruh terhadap voluntary disclosure level pada perusahaan Otomotif di Bursa Efek Indonesia.

\section{METODELOGI PENELITIAN \\ Objek dan Lokasi Penelitian}

Dalam penelitian ini yang menjadi lokasi penelitian adalah Perusahaan Otomotif yang terdaftar di Bursa Efek Indonesia (BEI). Variabel yang menjadi objek dalam penelitian ini yaituVoluntari Disclouse Level, Efek Entrenchment, Alignment dan Komisaris Dewan Independen.

\section{Populasi dan Sampel Populasi}

Populasi merupakan keseluruhan obyek penelitian yang akan di teliti. Menurut Sugiyono (2007), populasi adalah wilayah generalisasi yang terdiri atas obyek atau subyek yang mempunyai kualitas dan karakteristik tertentu yang di tetapkan oleh peneliti sesuai dengan kebutuhan dari penelitiannya. Populasi dalam penelitian ini adalah seluruh perusahaan Otomotif yang terdaftar di Bursa Efek Indonesia (BEI) periode tahun 2014 - 2017 dengan jumlah perusahaan adalah sebanyak 13 perusahaan.

\section{Sampel}

Sampel dalam penelitian ini berjumlah sebanyak 12 sampel dengan tahun penelitian sebanyak 3 tahun.Pengambilan sampel dalam penelitian ini dilakukan dengan menggunakan metode purposive sampling method.Menurut Sugiyono (2008:124) purposive samplingmethod yaitu "penentuan sampel atas dasar kesesuaian karakteristik dan kriteria tertentu".

Adapun yang menjadi kriteria pemilihan sampel dalam penelitian ini adalah sebagai berikut :

1. Perusahaan dalam penelitian ini adalah perusahaan otomotif yang terdaftar di Bursa Efek Indonesiadari tahun $2014-2017$.

2. Perusahaan mempublikasikan laporan keuangan 2014 - 2017.

Berdasarkan kriteria tersebut maka jumlah perusahaan yang sesuai kriteria di tampilkan pada tabel 1berikut ini :
Tabel 1 Kriteria Sampel

\begin{tabular}{|c|l|c|}
\hline $\begin{array}{l}\mathrm{N} \\
\mathrm{O}\end{array}$ & \multicolumn{1}{|c|}{ Kriteria Pemilihan Sampel } & $\begin{array}{c}\text { Jumlah } \\
\text { Perusahaan }\end{array}$ \\
\hline 1. & $\begin{array}{l}\text { Perusahaan Manufaktur yang terdaftar di } \\
\text { Bursa Efek Indonesia periodepenelitiantahun } \\
2016 .\end{array}$ & 13 \\
\hline 2 & $\begin{array}{l}\text { Perusahaan tidak mempublikasikan laporan } \\
\text { keuangan }\end{array}$ & 1 \\
\hline Jumlah sampel & 12 \\
\hline Periode penelitian & 4 \\
\hline Jumlah pengamatan & 48 \\
\hline
\end{tabular}

Sumber : Hasil penelitian, (2018)

Berdasarkan kriteria tersebut diatas maka jumlah sampel pada penelitian ini berjumlah 48 perusahaan .

\section{Teknik Pengumpulan Data}

Menurut Kuncoro (2009:145), Data adalah sekumpulan informasi yang diperlukan untuk pengambilan keputusan. Dalam penelitian ini menggunakan data sekunder yaitu data yang telah dikumpulkan oleh lembaga pengumpulan data dan dipublikasikan kepada masyarakat pengguna data (Kuncoro, 2009:148). Data sekunder dalam penelitian ini adalah data yang diperoleh dari www.idx.co.id selama tahun 2014-2016 untuk memperoleh data laporan keuangan yang dibutuhkan untuk penelitian.

Teknik pengumpulan data yang digunakan dalampenelitianiniyaitu dengan menggunakan teknik dokumentasi yaitu teknik pengumpulan data dengan cara pengumpulan, pencatatan, dan pengkopian laporanlaporankeuanganperusahaanOtomotifyangterdaftardiBur sa Efek Indonesia.

\section{Uji Asumsi Klasik}

Metode analisis data yang digunakan adalah model analisis regresi berganda dengan bantuan software SPSS for windows versi 20.00. Penggunaan metode analisis regresi dalam pengujian hipotesis, terlebih dahulu diuji apakah model tersebut memenuhi asumsi klasik atau tidak. Pengujian meliputi uji normalitas, uji autokorelasi, uji multikolinearitas, dan uji heteroskesdastisitas.

\section{Uji Normalitas}

Pengujian ini dimasudkan untuk mengetahui apakah dalam model regresi, variabel pengganggu atau residual mempunyai distribusi normal. Menurut Ghozali (2005:147) uji normalitas dapat dideteksi dengan dua cara yaitu: analisis grafik (Normal P-Plots dan histogram) dan analisis statistik melalui uji Kolmogrov Smirnov (K-s).Adapun ketentuan yang digunakan pada pengujian ini adalah sebagai berikut:

\section{Normal P-Plots}


2. Histogram

3. Uji Kolmogorov Smirnov (K-s)

\section{Uji Autokorelasi}

Autokorelasi yaitu adanya hubungan antara kesalahan pengganggu yang muncul pada data runtut waktu (time series).Dalam penaksiranmodel regresi linier mengandung asumsi bahwa tidak terdapat autokorelasi antara kesalahan pengganggu. Pengujian autokorelasi dapat dilakukan dengan menghitung Durbin-Wetson (d), dengan membandingkan nilai d terhadap dl dan du. Setelah menghitung nilai statistik selanjutnya dibandingkan dengan dari tabel dengan tingkat signifikan 5\%. Pengambilan keputusan dapat didasarkan pada (Ghozali, 2001:60):

a. Bila nilai DW terletak di antara batas atas atau upperbound (du) dan (4-du), maka koefisien korelasi autokorelasi sama dengan nol, berarti tidak ada autokorelasi.

b. Bila nilai DW lebih rendah daripada batas bawah atau lower bound ( $\mathrm{dl}$ ), maka koefisien autokorelasi lebih besar daripada nol, berarti ada autokorelasi positif.

c. Bila nilai DW lebih besar daripada (4-dl), maka koefisien autokorelasi lebih kecil daripada nol, berarti ada autokorelasi negatif.

d. Bila nilai DW terletak diantara batas atas (du) dan batas bawah (dl) atau DW terletak antara (4-du) dan (4-dl), maka hasilnya tidak dapat disimpulkan.

Menurut Ghozali (2005:95), pengambilan keputusan autokorelasi ada 5 dapat dilihat pada tabel 2 berikut ini :

\section{Tabel 2 Pengambilan Keputusan Autokorelasi}

\begin{tabular}{lcc}
\multicolumn{1}{c}{ Hipotesis nol } & Keputusan & Jika \\
Ada autokorelassi positif & Tolak Ho & $0<\mathrm{d}<\mathrm{dl}$ \\
$\begin{array}{l}\text { Tidak ada autokorelasi } \\
\text { positif }\end{array}$ & No desicision & $\mathrm{dl} \leq \mathrm{d} \leq \mathrm{du}$ \\
Ada autokorelasi negative & Tolak Ho & $4-\mathrm{dl}<\mathrm{d}<$ \\
& & 4 \\
$\begin{array}{l}\text { Tidak ada autokorelasi } \\
\text { negative }\end{array}$ & No desicision & $4-\mathrm{du} \leq \mathrm{d}$ \\
& & $\leq 4-\mathrm{dl}$ \\
$\begin{array}{l}\text { Tidak ada autokorelasi } \\
\text { positif atau negatif }\end{array}$ & Tolak Ho & $\mathrm{du}<\mathrm{d}<4$ \\
\end{tabular}

\section{Uji Multikolinearitas}

Pengujian multikolinearitas digunakan fasilitas yang disediakan SPSS yaitu dengan melihat VIF dari masing-masing variabel.Jika nilai VIF (Variance Inflation Factor) lebih rendah dari 10, maka dapat disimpulkan bahwa tidak ada multikolinearitas yang serius antara variabel independen dalam model.Ghozali (2006:97) menyebutkan bahwa hasil perhitungan nilai Variance Inflation Factor (VIF) dalam model regresi masing-masing variabel tidak bernilai diatas 10 maka tidak mengandung adanya multikolinearitas.

\section{Uji Heteroskesdastisitas}

Uji heteroskedastisitas bertujuan untuk menguji terjadinya perbedaan varian residual suatu periode pengamatan ke periode yang lain. Pengujian dilakukan dengan menggunakan grafik scatterplot dan uji Glejser. Ghozali (2006: 125) mengungkapkan bahwa "uji heteroskesdastisitas bertujuan untuk menguji apakah terjadi ketidaksamaan variance dari residual suatu pengamatan ke pengamatan yang lain dalam model regresi". Model regresi yang baik adalah jika variance dari residual suatu pengamatan kepengamatan lain berbeda (heteroskesdastisitas).

Metode yang digunakan untuk mendeteksi heteroskesdastisitas adalah menggunakan grafik plot antara nilai terikat (ZPRED) dengan residunya (SRESID). Deteksi ada tidaknya hetersokesdastisitas adalah dengan melihat ada tidaknya pola tertentu yang teratur di dalam grafik scatterplot antara SRESIS dengan ZPRED di mana sumbu $Y$ adalah $Y$ yang telah diprediksi dan sumbu $\mathrm{X}$ adalah residunya.Jika ada pola tertentu, maka mengindikasikan bahwa terjadi heterokedastisitas.Begitu juga sebaliknya, jika tidak ada pola tertentu, maka tidak terjadi heterokedastisitas. Hasil grafik scatterplot ini akan ditunjang dengan uji glejser dengan melihat nilai signifikansinya.

Apabila nilai signifikansinya lebih besar dari tingkat signifikansinya $(0,05)$, maka mengindikasikan bahwa tidak terjadi heterokedastisitas.

\section{Metode Analisis Data}

Analisis data adalah kegiatan mengolah data yang telah terkumpul kemudian dapat memberikan interprestasi pada hasil-hasil tersebut. Kegiatan dalam analisis data meliputi: pengelompokan data tiap variabel yang diteliti, melakukan perhitungan untuk menguji hipotesis yang diajukan.

Analisa dilakukan dengan menggunakan metode regresi linier berganda yang menghubungkan satu variabel dependen dengan beberapa variabel independen. Analisa ini bertujuan untuk melihat faktorfaktor yang mempengaruhi cost of debt Perbankan di Bursa Efek Indonesia. Persamaan regresi berganda yang digunakan dalam penelitian ini adalah sebagai berikut:

$$
\mathrm{Y}=\mathrm{a}+\mathrm{b}_{1} \mathrm{X}_{1}+\mathrm{b}_{2} \mathrm{X}_{2}+\mathrm{b}_{3} \mathrm{X}_{3}+\mathrm{e}
$$

Dimana: 


$$
\begin{array}{ll}
\mathrm{Y} & =\text { Voluntary Disclose Level } \\
\mathrm{a} & =\text { Konstanta } \\
\mathrm{b}_{1,2,3} & =\text { Koefisien Regresi } \\
\mathrm{X}_{1} & =\text { Entrenchment } \\
\mathrm{X}_{2} & =\text { Alignment } \\
\mathrm{X}_{3} & =\text { Dewan Komisaris Independen } \\
\mathrm{e} & =\text { error }
\end{array}
$$

\section{Pengujian Hipotesis}

Pengujian hipotesis dilakukan apabila model regresi terbebas dari penyimpangan asumsi klasik.Jika model telah memenuhi pengujian asumsi klasik, maka langkah selanjutnya adalah melakukan uji statistik.Pengujian statistik ini digunakan untuk menentukan menerima atau menolak hipotesis yang ditujukan.

\section{Uji t (parsial)}

Uji t dilakukan untuk melihat pengaruh variabel independen terhadap variabel dependen secara parsial. Bila $t_{\text {hitung }}>t_{\text {tabel }}$ dengan tingkat signifikan di bawah 5\%, maka dapat disimpulkan bahwa secara parsial variabel independen berpengaruh signifikan terhadap variabel dependen. Jika $t_{\text {hitung }}$ $<\mathrm{t}_{\text {tabel }}$ dengan tingkat signifikan di atas 5\%, maka dapat disimpulkan bahwa variabel independen tidak berpengaruh terhadap variabel dependen.

2. Uji F (simultan)

Pengujian ini bertujuan untuk mengetahui pengaruh variabel independen secara bersama-sama terhadap variabel dependen dengan melihat nilai signifikansi F. Bila $f_{\text {hitung }}>f_{\text {tabel }}$ dengan tingkat signifikan di bawah 5\%, maka dapat disimpulkan bahwa secara parsial variabel independen berpengaruh signifikan terhadap variabel dependen. Jika $f_{\text {hitung }}<f_{\text {tabel }}$ dengan tingkat signifikan di atas 5\%, maka dapat disimpulkan bahwa variabel independen tidak berpengaruh terhadap variabel dependen. (Ghozali, 2006:260).

\section{HASIL PENELITIAN DAN PEMBAHASAN Hasil Penelitian}

Pada hasil penelitian ini akan dibahas mengenai profilperusahaan,analisis pengaruh Efek Entrenchment, Aligment Dan Dewan Komisaris Independen Terhadap Voluntary Disclosure Pada Perusahaan Otomotif Yang Terdaftar Di Bursa Efek Indonesia Periode 2014-2017

\section{Profil Perusahaan Otomotif di Bursa EfekIndonesia pada Periode Penelitian 2014-2017}

Perusahaan yang menjadi sampel pada penelitian ini adalah 11 perusahaan Otomotif di Bursa Efek Indonesia selama periode 2008-2012. Profil perusahaan-perusahaan tersebut adalah sebagai berikut:

1.PT Astra International Tbk (IDX: ASII) didirikan pada tahun 1957 dengan nama PT Astra International
Incorporeted. Pada tahun 1980 perseroan mengubah namanya menjadi PT Astra International Tbk. Ruang lingkup kegiatan perseroan adalah perdagangan umum, perindustrian, jasa pertambangan, pengangkutan, pertanian, pembangunan dan jasa konsultasi, sedangkan ruang lingkup kegiatan utama anak perusahaan meliputi perakitan dan penyaluran mobil, sepeda motor berikut.

2. PT Astra Otoparts Tbk (IDX: AUTO) didirikan tanggal 20 September 1991 dengan nama PT Federal Adiwiraserasi. Perusahaan memulai kegiatan komersialnya pada tahun 1991. Ruang lingkup kegiatan Perusahaan terutama bergerak dalam perdagangan suku cadang kendaraan bermotor baik lokal maupun ekspor dan manufaktur dalam bidang industri logam, plastik dan suku cadang kendaraan bermotor. Saat ini kegiatan pemasaran Perusahaan meliputi dalam dan luar negeri termasuk Asia, Timur Tengah, Oceania, Amerika Selatan, Eropa dan Afrika, dan memiliki divisi perdagangan yang beroperasi di Singapura dan anak perusahaan di Australia. Perusahaan tergabung dalam kelompok usaha Astra Grup. Pabrik Perusahaan berlokasi di Jakarta dan Bogor dan kantor pusatnya beralamat di Jalan Raya Pegangsaan Dua Km. 2,2, Kelapa Gading, Jakarta.

3. PT Garuda Metalindo Tbk (IDX: BOLT) PT Garuda Metalindo Tbk ("Perusahaan") didirikan di Republik Indonesia berdasarkan Akta Notaris dari Lenny Budiman, S.H., Notaris di Jakarta No. 28 tanggal 15 Maret 1982. Akta pendirian ini telah disahkan oleh Menteri Kehakiman Republik.

4. PT Indo Kordsa Tbk (IDX: BRAM) didirikan pada tanggal 8 Juli 1981. Perseroan mulai beroperasi secara komersial pada tanggal 1 April 1987. Perseroan ini bergerak dalam bidang pembuatan dan pemasaran ban, filament yam (serat-serat nylon, polyester, rayon), benang nylon untuk ban dan bahan baku polyster. Induk utama dari perseroan adalah kordsa Global Endustriyel Iplik Ve KordBesi Sanayi Ve Ticaret A.S., suatu perusahaan yang berdomisili di Turki. Perseroan yang berdomisili di Indonesia dengan kantor pusat dan pabrik peralokasi di Jl. Pahlawan, Desa Karang Asem Timur, Citeureup, Bogor.

5. PT Goodyear Indonesia Tbk (IDX: GDYR) didirikan pada tanggal 26 Januari 1976 dengan nama NV The Goodyear Tire dan Rubber Company limited dan pada tanggal 31 Oktober 1977 berubah nama menjadi PT Goodyear Indonesia Tbk. Perusahaan mulai beroperasi pada tahun 1917. Perusahaan ini bergerakk dalam bidang industri ban untuk kendaraan bermotor dan pesawat terbang serta komponen lain yang terkait, penyaluran dana eskspor ban. Induk utama perusahaan adalah The Goodyear Tire \& Rubber Company, sebuah perusahaan yang berdiri dan berkedudukan di Amerika Serikat. 
6.PT Gajah Tunggal Tbk (IDX : GJTL) PT. Gajah Tunggal Tbk (Perusahaan) didirikan berdasarkan akta notaris No. 54 tanggal 24 Agustus 1951 dari Raden Meester Soewandi, SH, notaris publik di Jakarta. Akta pendirian ini disahkan oleh Menteri Kehakiman Republik Indonesia dalam Surat Keputusannya No. J.A.5/69/23 tanggal 29 Mei 1952 serta diumumkan dalam Berita Negara Republik Indonesia No. 63 tanggal 5 Agustus 1952, Tambahan No. 884. Anggaran Dasar Perusahaan telah disesuaikan dengan Undang-Undang No. 40 tahun 2007 mengenai Perseroan Terbatas, dengan akta No. 13 tanggal 22 Nopember 2007 dari Amrul Partomuan Pohan SH, Lex Legibus Magister, notaris di Jakarta dan telah memperoleh persetujuan dari Menteri Hukum dan Hak Asasi Manusia Republik Indonesia dengan Surat Keputusannya No. C-06556.HT.01.04-TH.2007 tanggal 13 Desember 2007.

7. Indomobil Sukses International Tbk (IDX: IMAS) Perusahaan dan anak perusahaan selanjutnya disebut "grup" didirikan dan menjalankan kegiatan usahanya di Indonesia. Ruang lingkup kegiatan grup bergerak dalam bidang perakitan dan distribusi kendaraan bermotor roda empat, bisdang truk dengan merek 'suzuki' 'nissah' 'volvo' 'volkswagen' 'Ssangyong' 'AUDI' 'hino, dan lainnya beserta kendaraan bermotor roda dua beserta suku cadangnya, perbengkelan, alatalat berat, jasa keuangan, pembiayaan konsumen.

8. PT Indospring Tbk (IDX: INDS) berkedudukan di Gresik, didirikan pada tanggal 5 Mei 1978. Perusahaan mulai berproduksi secara komersial pada tahun 1979.Ruang lingkup dari aktivitas Perusahaan bergerak dalam bidang industri spare parts kendaraan bermotor khususnya pegas, yang berupa leaf spring (pegas daun) dan coil spring (pegas spiral) beralamat di Jalan Mayjend Sungkono nomor 10, Segoromadu, Gresik 61123, Jawa Timur.

9. PT Multi Prima Sejahtera Tbk (IDX : LPIN) PT Multi Prima Sejahtera ("perusahaan") p/h lippo enter prises Tbk didirikan pada tanggal 7 januari 1982 berdasarkan akta no.9 dari notaris Misahardi Wilamarta, S.H. Akta pendirian tersebut telah disahkan oleh menteri kehakiman dalam surat keputusan No. C2 302.H.01.01-TH.84 tanggal 14 januari 1984 dan di umumkan dalam lembaran berita Negara No.82, Tambahan No.2417 tanggal 13 oktober 1989. Anggaran dasar perusahaan telah mengal;ami beberapa kali perubahan, terakhir dengan akta No 137 tanggal 27 juni 2001 dari notaris yang sama. Sehubungan dengan antara lain perubahan nama perusahaan menjadi PT. Multi Prima Sejahtera Tbk.

10. PT. Multistrada Arah Sarana Tbk (IDX:MASA)PT. Multistrada Arah Sarana Tbk ("Perusahaan") didirikan di Republik Indonesia pada tanggal 20 Juni 1988 dengan nama PT Oroban Perkasa dalam rangka Undangundang Penanaman Modal
Dalam Negeri No. 6 Tahun 1968, yang diubah dengan Undang-undang No. 12 Tahun 1970, berdasarkan Akta Notaris Lukman Kirana, S.H., No. 63. Akta pendirian disahkan oleh Menteri Kehakiman Republik Indonesia dalam Surat Keputusan No. C2- 8932.HT.01.01TH.88 tanggal 20 September 1988, serta diumumkan dalam Berita Negara No. 41, Tambahan No. 1877 tanggal 22 Mei 1990. Anggaran Dasar Perusahaan telah mengalami beberapa kali perubahan, yang terakhir melalui Akta Notaris Kumala Tjahjani Widodo, S.H., M.H., M.Kn., No. 48, tanggal 19 Desember 2011, mengenai penunjukan anggota dewan komisaris baru dan peningkatan modal dasar Perusahaan.

11. PT Nipress Tbk (Perusahaan) didirikan dalam rangka Undang-Undang Penanaman Modal Dalam Negeri No. 6 tahun 1968 yang telah diubah dengan Undang-Undang No. 12 tahun 1970 berdasarkan akta No. 295 tanggal 24 April 1975 dari Ridwan Suselo, S.H., notaris di Jakarta. Akta pendirian ini telah disahkan oleh Menteri Kehakiman Republik Indonesia dalam Surat Keputusannya No. Y.A.5/271/22 tanggal 19 Agustus 1975, serta diumumkan dalam Lembaran Berita Negara Republik Indonesia No. 42 tanggal 25 Mei 1976, Tambahan No. 394. Anggaran Dasar Perusahaan telah mengalami beberapa kali perubahan, terakhir dengan akta No. 548 tanggal 27 Juni 2014 dari Selly Suwignyo, S.H., M.Kn.,

12. PT Selamat Sempurna Tbk (IDX: SMSM) didirikan di Indonesia pada tanggal 19 Januari 1976. Perusahaan memulai kegiatan operasi komersialnya sejak tahun 1980. Ruang lingkup kegiatan Perusahaan terutama adalah bergerak dalam bidang industri alatalat perlengkapan (suku cadang) dari berbagai macam alatalat mesin pabrik dan kendaraan, dan yang sejenisnya. Perusahaan berkedudukan di Jakarta, dengan kantor pusat di Wisma ADR, Jalan Pluit Raya I No. 1, Jakarta Utara, sedangkan pabriknya berlokasi di Jakarta dan Tangerang.

\section{Pengujian Asumsi Klasik Uji Normalitas}

Uji Normalitas bertujuan untuk menguji apakah dalam model regresi variabel dependen dan variabel independen keduanya mempunyai distribusi normal atau tidak. Model regresi yang baik adalah memiliki distribusi normal atau mendekati normal. Menurut Ghozali (2006:148) mengungkapkan bahwa ketentuan grafik normality probability plot jika data menyebar disekitar garis diagonal dan mengikuti arah garis diagonal maka model regresi memenuhi asumsi normalitas. Berdasarkan hasil uji normalitas dengan alat bantu komputer yang menggunakan program SPSS 20.00, dapat terdilihat hasil seperti pada Gambar 2 berikut : 


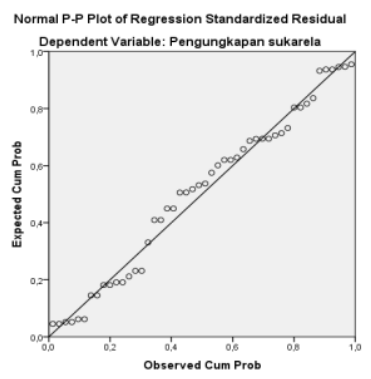

Gambar 2 grafik normality probability plot Sumber : Data diolah (2019)

Berdasarkan gambar 2 grafik normal plot, menunjukkan bahwa model regresi layak dipakai dalam penelitian ini karena pada grafik normal plot terlihat titiktitik menyebar disekitar gari diagonal serta penyebarannya mengikuti arah garis diagonal sehingga memenuhi asumsi normalitas. Pengujian normalitas data juga dilakukan menggunakan uji Kolmogrov-Smirnov Test. Hasil pengujian normalitas dapat dilihat pada Tabel 3 berikut ini :

\section{Tabel 3 Hasil Uji Normalitas Analisis Statistik Melalui Uji Kolmogrov Smirnov (K-S)}

\begin{tabular}{|l|l|r|}
\hline \multicolumn{2}{|c|}{ One-Sample Kolmogorov-Smirnov Test } \\
\hline \multicolumn{2}{|l|}{} & $\begin{array}{r}\text { Standardize } \\
\text { d Residual }\end{array}$ \\
\hline \multirow{2}{*}{ N } & Mean & 0 E-7 \\
\cline { 2 - 3 } & $\begin{array}{l}\text { Std. } \\
\text { Deviation }\end{array}$ &, 96755889 \\
\hline \multirow{3}{*}{ Most Extreme Differences } & Absolute &, 099 \\
\cline { 2 - 3 } & Positive &, 064 \\
\cline { 2 - 3 } & Negative &,- 099 \\
\hline Kolmogorov-Smirnov Z \\
\hline Asymp. Sig. (2-tailed) &, 684 \\
\hline \multicolumn{2}{|l|}{ a. Test distribution is Normal. } \\
\hline b. Calculated from data. \\
\hline
\end{tabular}

Sumber : Data Diolah (2019)

Menurut Ghozali (2006:149) mengungkapkan bahwa ketentuan uji Kolmogrov Smirnov (K-s)jika nilai signifikan >0,05 maka distribusi data normal. Berdasarkan hasil out put SPSS 20.0 dari Tabel 4.2 terlihat bahwa nilai Kolmogrov Smirnov (K-s) adalah 0,684 dengan Asymp. Sig. (2-tailed) sebesar 0,737 (>0.05) maka dapat disimpulkan bahwa instrumen dalam penelitian berdistribusi normal.

\section{Uji Multikolinieritas}

Uji Multikolinieritas adalah situasi adanya korelasi variabel-variabel bebas diantara satu dengan yang lain.Model regresi berganda harus terbebas dari multikolinieritas untuk satu variabel dependennya.Untuk mendeteksi ada tidaknya multikolinieritas dalam model regresi dapat dilihat dari nilai Tolerance dan Variance
Inflation Factor (VIF).Kedua ukuran ini menunjukkan setiap variabel bebas manakah yang dijelaskan oleh variabel lainnya.Dalam pengertian sederhana setiap variabel bebas menjadi variabel terikat dan diregresi terhadap variabel bebas lainnya. Tolerance mengukur variabilitas variabel bebas yang terpilih yang tidak dapat dijelaskan dalam variabel bebas lainnya. Jika nilai tolerance $>0,10$ atau $\mathrm{VIF}<10$ maka terjadi multikolinieritas. Hasil pengujian multikolonieritas di uraikan pada Tabel 4 berikut ini :

Tabel 4 Uji Multikoleniearitas

\begin{tabular}{|l|l|r|r|}
\hline \multicolumn{2}{|c|}{ Coefficients $^{\text {a }}$} \\
\hline \multicolumn{2}{|c|}{ Model } & \multicolumn{2}{c|}{$\begin{array}{c}\text { Collinearity } \\
\text { Statistics }\end{array}$} \\
\cline { 3 - 4 } \multicolumn{2}{|c|}{} & $\begin{array}{c}\text { Toleran } \\
\text { ce }\end{array}$ & VIF \\
\hline 1 & (Constant) & & \\
\hline & Efek Entracment &, 801 & 1,248 \\
\hline & Efek Aligment &, 728 & 1,373 \\
\hline & Peran Dewan Komisaris &, 878 & 1,139 \\
\hline \multicolumn{3}{|c|}{ a. Dependent Variable: Pengungkapan sukarela } \\
\hline
\end{tabular}

Sumber : Hasil Penelitian 2019 (data diolah)

Hasil perhitungan nilai tolerance menunjukkan tidak ada variabel independen yang memiliki nilai tolerance kurang dari 0,10 yang berarti tidak ada kolerasi antara variabel independen. Hasil perhitungan nilai variance inflation factor (VIF) juga menunjukkan hal yang sama tidak ada satu variabel independen yang memiliki VIF lebih dari 10. Jadi dapat disimpulkan bahwa tidak ada multikolonieritas antara variabel independen dalam model regresi.

\section{Uji Autokorelasi}

Uji Autokorelasi yaitu adanya hubungan antara kesalahan pengganggu yang muncul pada data runtut waktu (time series). Dalam penaksiranmodel regresi linier mengandung asumsi bahwa tidak terdapat autokorelasi antara kesalahan pengganggu. Pengujian autokorelasi dapat dilakukan dengan menghitung Durbin-Watson (d), dengan membandingkan nilai d terhadap dl dan du. Setelah menghitung nilai statistik selanjutnya dibandingkan dengan dari tabel dengan tingkat signifikan 5\%. Hasil pengujian autokorelasi dapat dilihat dari tabel berikut:

\section{Tabel 5 Hasil Uji Autokorelasi}




\begin{tabular}{|l|c|r|r|r|r|}
\hline \multicolumn{7}{|c|}{ Model Summary $^{\mathbf{b}}$} \\
\hline $\begin{array}{l}\text { Mo } \\
\text { del }\end{array}$ & $\mathbf{R}$ & $\begin{array}{c}\text { R } \\
\text { Squar } \\
\mathbf{e}\end{array}$ & $\begin{array}{c}\text { Adjusted } \\
\text { R Square }\end{array}$ & $\begin{array}{c}\text { Std. } \\
\text { Error of } \\
\text { the } \\
\text { Estimate }\end{array}$ & $\begin{array}{c}\text { Durbin- } \\
\text { Watson }\end{array}$ \\
\hline 1 &, 482 &, 233 &, 180 & 2,41590 & 2,190 \\
\hline
\end{tabular}

Sumber : Hasil penelitian, data di olah (2019)

Berdasarkan tabel 5 nilai Durbin-Waston (DW) sebesar 2,190 nilai dl (batas luar) sebesar 1.406, dan nilai du (batas dalam) sebesar 1.670 (lihat tabel DurbinWaston). Nilai Durbin-Waston < (4-du) yaitu (4-1.670= $2,330)$ atau $1,670<2,190<2,330$, maka tidak ada autokorelasi baik autokorelasi positif maupun autokorelasi negatif.

\section{Uji Heteroskedastisitas}

Uji heteroskedastisitas bertujuan untuk menguji apakah dalam model regresi terjadi ketidaksamaan variance dari residual satu pengamatan ke pengamatan lain. Jika variance residual satu pengamatan ke pengamatan lain tetap, maka disebut homoskedastisitas atau tidak terjadi heteroskedastisitas. Hasil sccatterplotpengujian heteroskedastisitas dengan menggunakan metode grafik dapat dilihat dari Gambar 3 sebagai berikut:

Gambar 3 Hasil Uji Heteroskedastisitas

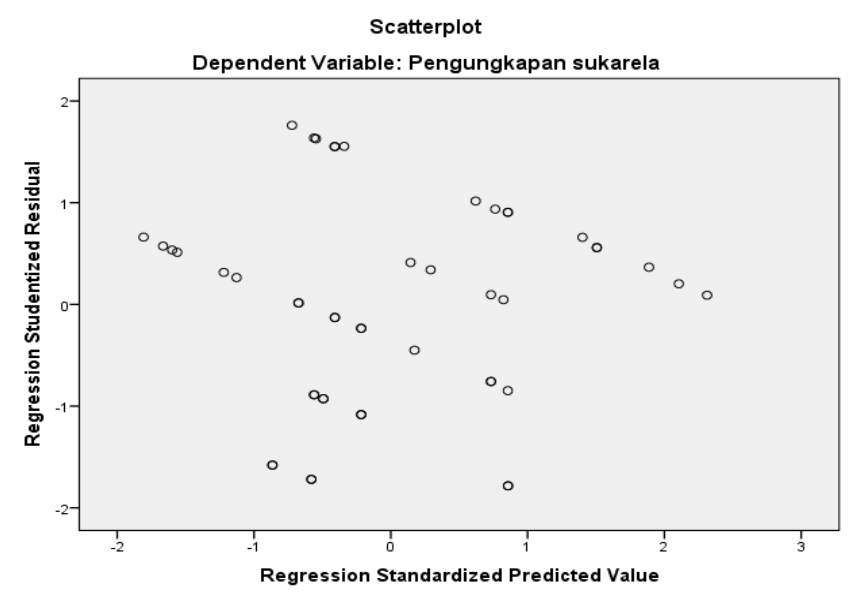

Sumber : Hasil penelitian, data diolah (2019)

Berdasarkan Gambar 3, maka dapat menggambarkan bahwa tidak terjadi heteroskedastisitas. Hal ini berdasarkan gambar grafik dimana titik-titik yang ada dalam grafik tidak membentuk pola tertentu yang jelas dan titik-titik tersebut tersebar di atas angka 0 pada sumbu Y.

\subsection{Hasil Regresi Linier Berganda}

Uji hipotesis adalah pengujian yang dilakukan oleh peneliti untuk mendapatkan hasil akhir dari penelitian yang telah di utarakan sebelumnya.Analisis yang digunakan untuk menguji hipotesis pada penelitian ini adalah analisis regresi linear sederhanayang bertujuan untuk mengukur kekuatan hubungan dan menunjukkan arah hubungan antara variabel independen terhadap variabel dependen.Dalam uji ini model regresi yang digunakan adalah model regresi linier sederhana. Hasil regresi dapat dilihat pada tabel 6 berikut :

Tabel 6 Hasil Analisis Regresi Linier Berganda

\begin{tabular}{|c|c|c|c|c|c|}
\hline \multicolumn{6}{|c|}{ Coefficients $^{\mathrm{a}}$} \\
\hline & Model & B & $\mathbf{t}_{\text {hitung }}$ & $\mathbf{t}_{\text {Tabel }}$ & Sig. \\
\hline \multirow[t]{4}{*}{1} & (Constant) & $\begin{array}{r}84,78 \\
1\end{array}$ & 13,414 & \multirow{4}{*}{1,680} &, 000 \\
\hline & Entrencment &,- 254 & $-2,492$ & & ,017 \\
\hline & Aligment &,- 729 & $-3,038$ & & ,004 \\
\hline & $\begin{array}{l}\text { Komisaris } \\
\text { Independen }\end{array}$ & ,478 & 2,103 & & ,041 \\
\hline
\end{tabular}

Sumber : Hasil penelitian, data di olah (2019)

Berdasarkan Tabel 6 dapatlah persamaan regresi berganda sebagai berikut :

$$
\mathrm{Y}=84,781-0,254 \mathrm{X}_{1}-0,729 \mathrm{X}_{2}+0,478 \mathrm{X}_{3}+\mathrm{e}
$$

Dari persamaan regresi linear berganda diatas dapat dijelaskan sebagai berikut:

a. Konstanta sebesar 84,781. Hal ini mengindikasikan bahwa voluntary disclosure mempunyai nilai sebesar 84,781 apabila variabel independen dianggap konstan (bernilai nol).

b. Nilai koefisien $\left(b_{1}\right)$ untuk variabel efek entracment bernilai negatif sebesar $-0,254$, hal ini menunjukkan bahwa setiap penurunan efek entracment sebesar 1\% maka akan meningkatkan voluntary disclosure sebesar 2,54\%. Begitu juga sebaliknya terhadap peningkatan efekentracment yang diterima sebesar $1 \%$ maka akan menurunkan voluntary disclosure sebesar $2,54 \%$.

c. Nilai koefisien $\left(b_{2}\right)$ untuk variabel efek aligment bernilai negatif sebesar 0,729, hal ini menunjukkan bahwa setiap penurunan efek aligment sebesar 1\% maka akan menurunkan voluntary disclosure sebesar 72,9\%. Begitu juga sebaliknya terhadap peningkatan efek aligment yang diterima sebesar $1 \%$ maka akan meningkat voluntary disclosure sebesar $72,9 \%$.

d. Nilai koefisien $\left(b_{3}\right)$ untuk variabel peran dewan komisaris bernilai positif sebesar 0,478, hal ini menunjukkan bahwa setiap prningkatan peran 
dewan komisaris sebesar $1 \%$ maka akan meningkatkan voluntary disclosure sebesar 47,8 $\%$. Begitu juga sebaliknya terhadap penurunan peran dewan komisaris yang diterima sebesar $1 \%$ maka akan menurunkan voluntary disclosure sebesar $47,8 \%$

\section{Hasil Uji Parsial}

Uji t menunjukkan seberapa besar pengaruh satu variabel independen secara individual dalam menerangkan variabel dependen.Pengujian ini dilakukan dengan ketentuan jika $t_{\text {hitung }}>t_{\text {tabel }}$ pada $\alpha=0.05$ maka hipotesis diterima atau dengan kata lain terdapat pengaruh yang signifikan antara satu variabel independen terhadap variabel dependen. Adapun hasil penelitian dapat di lihat pada Tabel 7 berikut ini :

Tabel 7 Hasil Uji Parsial

\begin{tabular}{|c|c|c|c|c|c|}
\hline \multicolumn{6}{|c|}{ Coefficients $^{\mathrm{a}}$} \\
\hline & Model & B & $\mathbf{t}_{\text {hitung }}$ & $\mathbf{t}_{\text {Tabel }}$ & Sig. \\
\hline 1 & (Constant) & $\begin{array}{r}84,7 \\
81\end{array}$ & 13,414 & \multirow{4}{*}{1,680} &, 000 \\
\hline & Entrencment & $\begin{array}{r}- \\
, 254\end{array}$ & $-2,492$ & & ,017 \\
\hline & Aligment & $\begin{array}{r}- \\
, 729\end{array}$ & $-3,038$ & & ,004 \\
\hline & $\begin{array}{l}\text { Komisaris } \\
\text { Independen }\end{array}$ & ,478 & 2,103 & &, 041 \\
\hline
\end{tabular}

Sumber : Hasil penelitian, data di olah (2019)

Nilai $t_{\text {tabel }}$ diperoleh dari degree of freedom $(\mathrm{df})$ untuk uji parsial 2 arah pada sampel $48 \mathrm{df}=\mathrm{N}-\mathrm{k}-1$ yaitu $48-3-1=44$ untuk hipotesis dengan nilai $\mathrm{t}$ pada signifikansi5\% atau 0,05 , maka nilai $t$ tabel yang diperoleh adalah sebesar 1,680.

\section{Pengaruh Efek Entrecment Terhadap Voluntary Disclosure Pada Perusahaan Otomotif Yang Terdaftar Di Bursa Efek Indonesia.}

Variabel efek entrecment $\left(\mathrm{X}_{1}\right)$ memperoleh $t_{\text {hitung }}$ sebesar $-2,492$ dan $t$ tabel sebesar 1.680 artinya $t$ hitung $>\mathrm{t}$ tabel atau $(2,492>1,680)$ dengan tingkat signifikansi lebih kecil dari 0,05 yaitu 0,017. Dengan demikian dapat disimpulkan bahwa $\mathrm{H}_{1}$ diterima dan dapat diartikan bahwa secara parsial efek entrecment berpengaruh negatif dan signifikan terhadap voluntary disclosure pada perusahaan Otomotif yang terdaftar di Bursa Efek Indonesia.

Pengaruh Aligment Terhadap Voluntary Disclosure Pada Perusahaan Otomotif Yang Terdaftar Di Bursa Efek Indonesia.
Variabel Aligment $\left(\mathrm{X}_{2}\right)$ memperoleh $\mathrm{t}_{\text {hitung }}$ sebesar $-3,038$ dan $t_{\text {tabel }}$ sebesar 1.680 artinya $t_{\text {hitung }}>\mathrm{t}$ tabel atau $(3,038>1,680)$ dengan tingkat signifikansi lebih kecil dari 0,05 yaitu 0,004. Dengan demikian dapat disimpulkan bahwa $\mathrm{H}_{2}$ diterima dan dapat diartikan bahwa secara parsial aligment berpengaruh negatif dan signifikan terhadap terhadap voluntary disclosure pada perusahaan Otomotif yang terdaftar di Bursa Efek Indonesia.

Pengaruh Dewan Komisaris Independen Terhadap Voluntary Disclosure Pada Perusahaan Otomotif Yang Terdaftar Di Bursa Efek Indonesia.

Variabel dewan komisaris independen $\left(\mathrm{X}_{3}\right)$ memperoleh $\mathrm{t}_{\text {hitung }}$ sebesar 2,103 dan $\mathrm{t}_{\text {tabel }}$ sebesar 1.680 artinya $t_{\text {hitung }}>\mathrm{t}_{\text {tabel }}$ atau $(2,103>1,680)$ dengan tingkat signifikansi lebih kecil dari 0,05 yaitu 0,041. Dengan demikian dapat disimpulkan bahwa $\mathrm{H}_{3}$ diterima dan dapat diartikan bahwa secara parsial dewan komisaris independen berpengaruh positif dan signifikan terhadap voluntary disclosure pada perusahaan Otomotif yang terdaftar di Bursa Efek Indonesia.

\section{Hasil Uji Simultan}

Uji ini dilakukan dengan menggunakan uji signifikan simultan yaitu uji $\mathrm{F}$, untuk menunjukkan apakah variabel bebas (independen) secara bersamasama mempunyai pengaruh terhadap variabel terikat (dependen).

Tabel 8 Hasil Uji Simultan ANOVA $^{\mathrm{a}}$

\begin{tabular}{|c|c|c|c|c|c|c|}
\hline \multicolumn{2}{|c|}{ Model } & \multirow{2}{*}{$\begin{array}{l}\begin{array}{r}\text { Sum of } \\
\text { Squares }\end{array} \\
77,857\end{array}$} & \multirow{2}{*}{$\begin{array}{r}\mathrm{df} \\
3 \\
\end{array}$} & \multirow{2}{*}{$\begin{array}{l}\text { Mean } \\
\text { Squar } \\
\text { e } \\
25,95 \\
2\end{array}$} & \multirow{2}{*}{$\begin{array}{c}\mathrm{F} \\
4,447\end{array}$} & \multirow{2}{*}{$\begin{array}{l}\text { Sig. } \\
, 008^{\mathrm{b}}\end{array}$} \\
\hline \multirow{3}{*}{1} & Regression & & & & & \\
\hline & Residual & 256,809 & 44 & 5,837 & & \\
\hline & Total & 334,667 & 47 & & & \\
\hline
\end{tabular}

Sumber : Hasil penelitian, data diolah (2019)

Nilai $\mathrm{F}_{\text {tabel }}$ diperoleh dari degree of freedom(df) untuk uji parsial 2 arah pada sampel 48, df $=\mathrm{N}-\mathrm{k}-1$ yaitu $48-3-1=44$ dengan df $1=2$ dan $\mathrm{df} 2$ $=44$ untuk hipotesis dengan nilai $\mathrm{F}$ pada signifikansi5\% atau 0,05 , maka nilai $F_{\text {tabel }}$ yang diperoleh adalah sebesar 2,816. Sedangkan $F_{\text {hitung }}$ sebesar 4,447 dengan nilai signifikan sebesar 0,008 pada taraf kepercayaan 95\%. Dengan demikian $\mathrm{F}_{\text {hitung }}>\mathrm{F}_{\text {tabel }}$ yaitu 4,447>2,816 dan nilai signifikan sebesar 0,008<0.05.Dari Hasil uji $F$ ini berarti menerima $\mathrm{H}_{4}$.Dengan demikian secara simultan efek entrecment, efek aligment dan dewan komisaris independen berpengaruh positif dan signifikan 
terhadap voluntary disclouse pada perusahaan otomotif yang terdaftar di Bursa Efek Indonesia.

\section{PEMBAHASAN \\ Pengaruh Efek Entrecment Terhadap voluntary disclosure Pada Perusahaan Otomotif Yang Terdaftar Di Bursa Efek Indonesia}

Hasil dari penelitian ini menunjukkan bahwa efek entrecment berpengaruh negatif dan signifikan terhadap voluntary disclosure. Hal ini ditunjukkan oleh hasil nilai $\mathrm{t}_{\text {hitung }}>\mathrm{t}_{\text {tabel }}$ yakni 2,492 $>1.680$ dan nilai signifikan sebesar $0.017<0.05$.Dengan demikian dapat disimpulkan bahwa $\mathrm{H}_{1}$ diterima dan dapat diartikan bahwa secara parsial efek entrecment berpengaruh negatif terhadap voluntary disclosure pada perusahaan Otomotif yang terdaftar di Bursa Efek Indonesia.Adanya pengaruh negatif menunjukkan bahwa, dengan adanyan pemegang saham pengedali dalam perusahaan tidak mampu meningkatkan jumlah pengungkapan sukarela dalam perusahaan.Hal ini disebabkan karena pemegang saham pengendali cenderung melalukan tindakan expropiasi yang hanya menguntungkan pihaknya sendiri.

Hasil penelitian yang dilakukan oleh Oktaviani (2016) sejalan dengan hasil penelitian ini dimana hasil penelitian menunjukkan bahwa efek entrecment berpengaruh negatif terhadap voluntary disclosure pad perusahaan Mufaktur yang terdaftar di Bursa Efek Indonesia.

Pengaruh Aligment Terhadap Voluntary Disclosure Pada Perusahaan Otomotif Yang Terdaftar Di Bursa Efek Indonesia

Variabel Aligment $\left(\mathrm{X}_{2}\right)$ memperoleh $\mathrm{t}_{\text {hitung }}$ sebesar $-3,038$ dan $t_{\text {tabel }}$ sebesar 1.680 artinya $t_{\text {hitung }}>t$ tabel atau $(3,038>1,680)$ dengan tingkat signifikansi lebih kecil dari 0,05 yaitu 0,018. Dengan demikian dapat disimpulkan bahwa $\mathrm{H}_{2}$ diterima dan dapat diartikan bahwa secara parsial aligment berpengaruh terhadap terhadap voluntary disclosure pada perusahaan Manufaktur yang terdaftar di Bursa Efek Indonesia.Artinya perusahaan otomotif secara umum pemegang saham pengendali dikuasi oleh investor asing sehingga punya kebebasan dalam rangka melakukan ekspropiasi.

Hasil penelitian yang dilakukan oleh Oktaviani (2016) sejalan dengan hasil penelitian ini dimana hasil penelitian menunjukkan bahwa efek aligment berpengaruh negatif terhadap voluntary disclosure pad perusahaan Mufaktur yang terdaftar di Bursa Efek Indonesia.

Pengaruh Dewan Komisaris Independen Terhadap Voluntary Disclosure Pada Perusahaan Otomotif Yang Terdaftar Di Bursa Efek Indonesia.

Variabel dewan komisaris independen $\left(\mathrm{X}_{3}\right)$ memperoleh $\mathrm{t}_{\text {hitung }}$ sebesar 2,103 dan $\mathrm{t}_{\text {tabel }}$ sebesar 1.680 artinya $t_{\text {hitung }}>t_{\text {tabel }}$ atau $(2,103>1,680)$ dengan tingkat signifikansi lebih kecil dari 0,05 yaitu 0,041. Dengan demikian dapat disimpulkan bahwa $\mathrm{H}_{3}$ diterima dan dapat diartikan bahwa secara parsial dewan komisaris independen berpengaruh positif terhadap terhadap voluntary disclosure pada perusahaan Otomotif yang terdaftar di Bursa Efek Indonesia.Artinya independen komisaris merupakan manajemen perusahaan yang berfungsi mengatur dan mengelola jalannya operasional perusahaan.

Hasil penelitian yang dilakukan oleh Oktaviani
(2016) menunjukkan bahwa dewan komisaris independenberpengaruh positif terhadap voluntary disclosure pada perusahaan Otomotif yang terdaftar di Bursa Efek Indonesia. Begitu juga dengan penelitian yang dilakukan oleh Fitriani (2014) yang menunjukkan bahwa dewan komisari independen berpengaruh terhadap voluntary disclosure.

\section{PENUTUP}

Kesimpulan

Berdasarkan pembahasan yang telah diuraikan maka dapat disimpulkan sebagai berikut :

1. Secara parsial efek entrecment berpengaruh negatif dan signifikan terhadap Voluntary Disclosure Pada Perusahaan Otomotif Yang Terdaftar Di Bursa Efek Indonesia. Hal ini dibuktikan dengan $t_{\text {hitung }}>t_{\text {tabel }}$ yaitu $-2,492>1,680$. Dan tingkat sig $<0,05$ yaitu 0,017 . Adanya pengaruh negatif menunjukkan bahwa, dengan adanyan pemegang saham pengedali dalam perusahaan tidak mampu meningkatkan jumlah pengungkapan sukarela dalam perusahaan.

2. Secara parsial Secara parsial efek alignment berpengaruh negatif dan signifikan terhadap Voluntary Disclosure Pada Perusahaan Otomotif Yang Terdaftar Di Bursa Efek Indonesia. Hal ini dibuktikan dengan $t_{\text {hitung }}>t_{\text {tabel }}$ yaitu $-3,038>1,680$. Dan tingkat sig $<0,05$ yaitu 0,004 . Artinya perusahaan otomotif secara umum pemegang saham pengendali dikuasi oleh investor asing sehingga punya kebebasan dalam rangka melakukan ekspropiasi.

3. Secara parsial Secara parsial Dewan Komisaris Independen berpengaruh positif dan signifikan terhadap Voluntary Disclosure Pada Perusahaan Otomotif Yang Terdaftar Di Bursa Efek Indonesia. Hal ini dibuktikan dengan $t_{\text {hitung }}>t_{\text {tabel }}$ yaitu $2,103>$ 1,680. Dan tingkat sig $<0,05$ yaitu 0,041 . Artinya independen komisaris merupakan manajemen perusahaan yang berfungsi mengatur dan mengelola jalannya operasional perusahaan.

4. Secara simultan efek entrecment, efek alignment dan Dewan Komisaris Independen berpengaruh positif dan signifikan terhadap Voluntary Disclosure Pada Perusahaan Otomotif Yang Terdaftar Di Bursa Efek Indonesia. Hal ini dibuktikan dengan $\mathrm{F}_{\text {hitung }}>\mathrm{F}_{\text {tabel }}$ yaitu $4,447>2.816$. Dan tingkat sig $<0,05$ yaitu 0,008 . 
Saran

Pada penelitian yang akan datang terdapat beberapa hal yang perlu diperhatikan, diantara adalah sebagai berikut:

1. Bagi perusahaan khususnya perusahaan Otomotif yang terdaftar di Bursa Efek Indonesia, untuk meningkatkan kepercayaan pemegang saham terhadap perusahaan.

2. Bagi penelitian selanjutnya variabel independen yang digunakan harus lebih dikembangkan seperti manajemen laba, profitabilitas dan ukurran perusahaan. Pengembanagan ini perlu dilakukan mengingat banyak variabel lain yang berperan dalam mempengaruhi voluntary disclosure.

\section{KEPUSTAKAAN}

Agustina (2015), Pengaruh corporate governance, struktur kepemilikan perusahaan, dan ukuran perusahaan terhadap biaya utang

Anthony dan Govindarajan (1995) Management Control System, Edisi 11, penerjemah: F.X. Kurniawan Tjakrawala, dan Krista. Penerbit Salemba Empat, Buku 2, Jakarta.

Arikunto, S (2002). Prosedur Penelitian, Suatu Pendekatan Praktek. Jakarta: PT. Rineka Cipta.

Bhojraj, S., dan Sengupta, P. (2003).Effect of Corporate Governance on Bond Ratings and Yiels: The Role of Institutional Investors and Outside Directors. Journal of Business, 76 (3), 455-475.

Brigham, Eugene F dan Joel F Houston.(2001). Manajemen Keuangan.Edisi.Delapan. Jakarta

Bursa, Efek Indonesia, (2015), Laporan Keuangan Auditan, Sumber : Http//.. www. Idx.co.id.

Chan dan Hsu, Ai Chi (2013) Earnings Management, Corporate Governance, and Auditor's Opinions : a Financial Distress Prediction Model. Vol 7 No 3.

Chen, Y.M. dan Jian J.Y. (2006). The Impact of Information Disclosure and Transparency Rankings System (IDTRs) and Corporate Governance Structure on Interest Cost of Debt.Working Paper, Taiwan: National Yunlin University of Science and Technology.

Fan, J. P. \& T. Wong (2002) Corporate ownership structure and the informativeness of accounting earnings in East Asia. Journal of Accounting and Economics: 401-425.

Ghozali, Imam (2005).AplikasiAnalisis Multivariate dengan Program SPSS..UniversitasDiponenogo. Semarang Godfrey, J., et al. (2010). Accounting Theory (7th ed.). New York: McGraw Hill
Hanafi, Mahmud M dan Abdul Halim. (2007). Analisa Laporan Keuangan. Yogyakarta:UPP YKPN

Halim, Abdul. (2003). Auditing :Dasar-Dasar Audit LaporanKeuangan. EdisiKetiga.Yogyakarta : UPP AMP YKPN

Isna Ningsih et. Al., (2009).Pengaruh Good Corporate Governance, Voluntary Disclosure Terhadap Biaya Hutang (Cost Of Debt) Pada Perusahaan Manufaktur Yang Terdaftar Di Bursa Efek Indonesia. Skripsi. Purwokerto: Universitas Muhammadiyah.

Ikatan Akuntansi Indonesia.(2001). Pedoman Standar Akuntansi Publik: Jakarta: SalembaEmpat.

Jensen, M.C. dan W. H. Meckling. (2006) "Theory of the Firm: Managerial Behaviour, Agency Cost and Capital Structure", Journal of Financial Economics

Juniarti dan A. A. Sentosa. 2009. Pengaruh Good Corporate Governance, Voluntary Disclosure terhadap Biaya Utang (Cost of Debt). Jurnal Akuntansi Keuangan, Vol. 11, No.2, November, 88-100.

Keputusan Menteri BUMN Kep-117/M-MBU/2002 tentang penerapan praktik good corporate governance

Kuncoro, M. (2009). Metode Riset Untuk Bisnis dan Ekonomi. Edisi ketiga. PT. Glora Aksara Pratama. Erlangga

La Porta, R., F. Lopez-De-Silanes, dan A. Shleifer. (1999) Corporate Ownership Around the World. The Journal of Finance, LIV (2): 471516.

Lin, I.H., Ko, C.H., Chang, Y.P., Liu, T.L., Wang, P.W., Lin, H.C., Huang, M.F., Yeh, Y.C., Chou, W.J., \& Yen, C.F. (2014). The Association between suicidality and internet addiction and activities in Taiwanese adolescents. Comprehensive Psychiatry, 55, 504-510.

Mulyadi, John Setiawan, (2001), Sistem Perencanaan dan Pengendalian Manajemen : Salemba Empat.

Midiastuty, P., Machfoedz, M., (2003).Analisis Hubungan Mekanisme Corporate.Governance dan Indikasi Manajemen Laba. Simposium Nasional Akuntansi VI

Nasution dan Doddy Setiawan, D (2007).“Pengaruh Corporate Governance Terhadap Manajemen Laba di Industri Perbankan”. Simposium Nasioal Akuntansi X, Makasar.

OECD Principles of Corporate Governance,. (2004). Organisation for Economic Co-Operation and Develovment, $\underline{\text { www.iasplus.com }}$ 
Volume 7, Nomor 1, Februari 2019

Piot, C., dan Piera, F.M. (2007). Corporate Governance, Audit Quality, and The Cost of Debt Financing of French Listed Companies

Rebecca, Yulissa. (2012). Pengaruh Corporate Governance Index, Kepemilikan Keluarga, Kepemilikan Institusional Terhadap Biaya Ekuitas dan Biaya Hutang. Skripsi. Jakarta: Universitas Indonesia.

Scott, William R. (2006). Financial AccountingTheory, 4th

Edition. Prentice Hall, NJ

Smith, C, and J. Warner (1979) On Financial

Contracting, An Analysis of Bond Covenants, Journal of Financial Economics, 7, 117-161.

Sugiyono. (2008). Metode Penelitian Bisnis, Cetakan

Kesebelas, Alfabeta, Bandung

Singgih dan Tjiptono, Fandy, (2008), Riset Pemasaran: Konsep dan Aplikasi dengan SPSS, PT Elex Media Komputindo, Jakarta.

Ujiyantho, Muh. Arief dan Bambang Agus Pramuka (2007) Mekanisme Corporate Governance, Manajemen Laba dan Kinerja

Keuangan.Jurnal Simposium Nasional

Akuntansi X. Makassar

Wijaya, R. E., 2009, Keberadaan Corporate Governance dan Kondisi Financial Distressed terhadap Voluntary Disclosure,Jurnal keuangan dan perbankan, Vol. 13, No. 3, September: 395-404

Widyaningdyah, Agnes Utari (2001) "Analisis Faktor Faktor yang Berpengaruh Terhadap Earnings Management pada Perusahaan Go Public di Indonesia”. Jurnal Akuntansi \& Keuangan Vol. 3, No. 2, November. Fakultas Ekonomi Universitas Kristen Petra

Yunita, Nancy. (2012). Pengaruh Corporate Governance Terhadap Voluntary Disclosure dan Biaya Hutang. Jurnal Ilmiah Mahasiswa Akuntansi

Yenibra (2014) Pengaruh Corporate Governance, KualitasAudit Dan Voluntary Disclosure Terhadap Biaya Utang(Studi Empiris Pada Perusahaan Go Public Yang TerdaftarDi Cgpi Tahun 2009-2012).

Zahra (2012), Good Corporate Governance dalam

Perusahaan, www. Isazahro.com 
